\title{
A CHAT WITH NEIL BESNER ${ }^{1}$
}

\author{
\% \\ NEIL BESNER, \\ Alinne BALduino P. FERNANDES ${ }^{2}$, MARIA LÚCIA VASCONCELlos ${ }^{3}$
}

$\mathrm{B}$ ased at the University of Winnipeg, Canada, Dr. Neil Besner is a specialist in Canadian Literature who has also worked occasionally with translation. Besides his native English, he is a fluent speaker of Portuguese, French and Spanish. Besner was born in Montreal, Canada, and spent part of his childhood in Rio de Janeiro, where he developed a taste for the Portuguese language and deep fondness for Brazilian culture. He has also spent a few years in the US, and then returned to Canada, where he graduated in English at McGill University, Montreal, in 1972, followed by his MA in American Literature at the University of Regina, Saskatchewan, in 1974. Besner completed his $\mathrm{PhD}$ in Canadian literature at the University of British Columbia in 1983. Besides his published translation of Carmen Lucia Oliveira's Flores Raras e Banalíssimas (1995), a biography-fiction of Elizabeth Bishop and Lota Macedo de Soares, his extensive C.V. features a wide range of publications. He has written two books namely, The Light of Imagination: Mavis Gallant's Fiction (1988) and Introducing Alice Munro's “Lives of Girls and Women” (1990) -, several articles on Canadian literature, translation and Brazilian Studies, and book reviews.

\footnotetext{
${ }^{1}$ The research that made this meeting possible was funded by PIBIC/CNPq from 2003 to 2004. Its most important outcome is the article "Explicitação e Omissão de Categorias Culturais em Flores Raras e Banalíssimas e Rare and Commonplace Flowers: Um Estudo baseado em Corpus de Pequena Dimensão” (Fernandes and Vasconcellos, 2008).

2 Alinne Balduino P. Fernandes concluded her PhD in Theatre and Translation Studies at Queen's University Belfast in November 2012. She is currently a postdoctoral researcher at Universidade de São Paulo, where she investigates female corporealities in Irishwomen playwriting. Her research interests are Translation Studies, Theatre Studies, Irish and Brazilian drama, and Feminism. Fernandes has published both nationally and internationally on translation and theatre translation, and has taught at both undergraduate and postgraduate levels in Brazil and the UK.

${ }^{3}$ Maria Lúcia Vasconcellos holds a PhD degree in English from Universidade Federal de Santa Catarina, Brazil, where she is currently an Associate Professor. Her research interests include Translation Studies (systematic mapping of the field, text analysis and translation and more recently Didactics of Translation), Systemic Functional Linguistics and corpus methodologies. In these areas she has published and lectured both nationally and internationally and supervised postgraduate work.
} 
With regard to the transcript that follows, although Dr. Alinne Balduino P. Fernandes interviewed Besner on the $7^{\text {th }}$ of March 2003, the transcript below had never been published before. To put it into context, this interview took place at the XVII ENPULI (Encontro Nacional de Professores Universitários de Língua Inglesa - The National Meeting of English Language University Tutors), when Fernandes, then an undergraduate student at UFSC (Universidade Federal de Santa Catarina), was carrying out her CNPq-funded research under the supervision of Dr. Maria Lúcia Vasconcellos. At that time, she was investigating how culture-specific items (cf. Aixelá, 1996) were dealt with in Besner's translation of Flores Raras $e$ Banalíssimas, published in North America in 2002 under the title Rare and Commonplace Flowers: The Story of Elizabeth Bishop and Lota Macedo de Soares. The book was recently adapted into film by Brazilian director Bruno Barreto in 2013 under the title Flores Raras in Brazil, and Reaching for the Moon in the US.

In this interview, Besner tackles issues that range from reception, the horizon of expectations of North American readers, and North American publishers to the positionality of the translator. For Besner, the translator is a writer, and, for this reason, who the translator is invariably affects his/her translation. Some ideas that are key to contemporary Translation Studies have come to surface during the chat, namely the politics involved in the translator-editor relationship, particularly with regard to what is referred to here as the subjectivity of the translator; otherness and translation; ethics; cultural appropriation; and "culture-specific items".

It is worth clarifying that the term "culture-specific item" stems from Javier Aixelá (1996: 57), which he defines as "a strictly cultural component, as opposed to, say, the linguistic or pragmatic ones”. Aixelá acknowledges the limitedness of the concept, since "in a language everything is culturally produced" (op. cit.). The concept, nonetheless, elucidates how a conflict emerges in any act of translation, particularly when it comes to references in the source culture that are not shared by the target culture. Aixelá, thus, elaborates the concept of culturespecific items as:

Those textually actualized items whose function and connotations in a source text involve a translation problem in their transference to a target text, whenever this problem is a product of the nonexistence of the referred item or of its different intertextual status in the cultural system of the readers of the target text. (Aixelá, 1996: 58)

Based on the notion of the lack of reference of culture-specific elements of the source culture in the target culture and on a reading of Flores Raras, the piece of research carried out at the time involved the investigation of how Besner, the translator, dealt with the translation (or not) of place names; people names; currency; food and beverages; means of transport; housing; clothing and accessories; fauna and flora; religious references; local institutions; political organisations; and leisure and work, which include references to traditional celebrations, as well as references to Brazilian music and literature (for more information on the outcomes of the research, see Fernandes \& Vasconcellos, 2008).

It is worth mentioning that, more than an interview per se, what follows is a chat with Besner, who could not resist speaking Portuguese with his carioca lilt. At the point when the transcription that follows begins, our chat had already been going on for a while, when we turned our attention to Flores Raras, and Besner's translation of the book into English, particularly to his choices with regard to the 
translation of culture-specific items. At the precise moment when the recording begins, we start talking about the omission of the name of the conservative political party UDN (União Democrática Nacional) in the translation.

$[\ldots]$

NEIL BESNER: Oh, you mean, so you thought there should be more explaining of what the [political] party [União Democrática Nacional] is? Is that what you mean?

Aline BALDUino P. FERNANDEs: Or maybe the name of the party in the text.

NeIL BeSNER: Aham, aham.

\section{A. B. P. FERNANDES: That was what I thought.}

NEIL BESNER: Yeah, no, I guess sometimes we didn't include the name; sometimes we just included an explanation of what it was without the name.

\section{A. B. P. FERNANDES: Oh, ok.}

NEIL BESNER: But most of the time, the names of things were there as well.

\section{A. B. P. FERNANDES: Oh, ok.}

NeIL BESNER: This is an exception. Because we thought it was important for the North American readers to have the name, and, yet the things seem a little strange for the North American reader, that's because they are strange. It should be; they should be there. They should be strange. Entendeu?

A. B. P. FERNANDES: They would sound very exotic to the American audience... And do you think it's more important to naturalise things [i.e. references that are specific to Brazilian culture]?

NEIL BESNER: That's a big problem.

\section{A. B. P. FERNANDES: So that the American audience can accept it better, digest it better.}

NeIL BESNER: It's a problem. If you explain everything to an American audience, so that they can digest it better, as you say, then, I think that you lose some things because Bishop, in Brazil, sometimes felt strange. And her poems are all about feeling strange in Brazil, about a foreign eyes não percebendo bem o que é o Brasil exatamente. She knew; she understood that. And her poems are precisely about that. So, if you naturalise things for an American reader, I think you lose that sense of strangeness, on one hand. On the other hand, if you make it too strange, then the American reader or the English speaking reader vão dizer: "O que é isso? Não quero saber." So, there's a balance that you have to strike, and it's not in the middle. You can’t just say, “oh, well, a little bit here, a little bit there.” It's difficult in each case. So in this case here [of omitting the name of the political party "União 
Democrática Nacional”], we decided, I guess... I don't even remember this case, but I guess we decided not to use the name. But you lose something, and you gain something. And it's difficult.

\section{A. B. P. FERNANDES: Translation is always about that, right?}

NeIL BESNER: Yeap, yeap. That's part of it.

A. B. P. FERNANDES: There are some translation scholars who say that, especially when you translate to powerful nations, like the US, to English speaking countries, translators tend to omit words because...

NEIL BESNER: Because the Americans will understand it?

\section{A. B. P. FERNANDES: Yeah.}

NeIL BESNER: So, they surrender.

A. B. P. FERNANDES: Yes, exactly. Especially because they're translating a text that is about an economically less powerful country, and their culture, their politics is not that important. Their colour is not so important.

NeIL BeSNER: I understand. Carmen felt quite strongly about that, as I do, as well. I don't think that there were many cases where we actually omitted a name in order to surrender, or homogenise, or naturalise for the target audience. I don't think there're too many cases like that. But there might be, I don't know. Maybe there aren't, maybe there are more, maybe we did it unconsciously. I'm not so sure. What we did was, I would write a chapter, send it to Carmen; go back and forth, back and forth, back and forth. And, it might be that we did it more than we think. I'm not sure. Somebody else would have to say it, I don't know. I'm not sure.

\section{A. B. P. FERnAndes: Don't you think that this is important to the American publishers as well?}

NeIL Besner: Well, the American publishers, they insisted on the index, and we said, "no."

\section{A. B. P. FERNANDES: They insisted on the index?}

NEIL BESNER: Yes, yes, they wanted an index very strongly.

\section{A. B. P. FERNANDES: Footnotes and things like that?}

NEIL BESNER: Well, they wanted explanations, and we said, "the kind of book this is will provide explanations, but we want to work them into the text. We want to add them into the text. We don't to want to interrupt the readers. It's not a scholarly book.” I don't think it works like this.

\section{A. B. P. FERNANDES: Yes, it would be an uncomfortable reading.}


NEIL BESNER: "We want them to read the story." That's what my original idea was. I said, "you know, Carmen, eles não vão entender todas essas referências, vamos fazer um glossary." Mas a gente descontou isso. "Então vamos meter no texto mesmo." So we took the whole glossary, went through piece by piece and inserted it into the text. We may have missed some things, obviously, like this one [the reference to the political party “União Democrática Nacional”]. And I don't know how much we missed. And the other thing is that I'm unreliable in that sense because I've lived in Brazil. And some things that I thought people would understand, I might be wrong, so it's judgement. And you never know how much you have to explain, how much you shouldn't. So, I don't know, but that's an interesting question. And the publisher does have a kind of power. And the culture that you are translating for does have a kind of power as well. You're always thinking to yourself, "What will these people understand? What do they want? And what's their vision of Brazil before they come to this text?" And let's face it: one tendency of American culture particularly is to exoticise and fetishise Brazilian culture. They say, “oh, it's erotic, and sensual, and Bossa Nova, and the girl from Ipanema...”

\section{A. B. P. FERNANDES: Sultry...}

NEIL BESNER: And sultry e tudo isso. Então, that's operating in the back here [the fetishisation and exoticisation of Brazilian culture in the eyes of American readers], and trying to raise in a paper some of that, but it's that kind of vai-vém thing that happens. So, on one hand, you don't want to reinforce that attitude, and, on the other, you're part of it, too, so... I don't know what the answer is.

\section{A. B. P. FERNANDES: What if a Brazilian who had very good English decided to translate Flores Raras into English?}

NEIL BESNER: It would be different.

\section{A. B. P. FERnANDES: Yeah, very different; maybe the Americans wouldn't like it that much.}

NEIL BESNER: Maybe...

\section{A. B. P. FERNANDES: Because it would be translated with Brazilian eyes...}

NeIL BESNER: Yeah, right, that's right. And, I mean, I've lived here for some time, I speak the language, but I'm not Brazilian.

\section{A. B. P. FERNANDES: Yeah, of course.}

NEIL BESNER: I'm Canadian, and I'm North American. And, if I said I wasn't, that would be even more deceptive. So, without doubt, if a Brazilian translated it, he or she would write a different book.

\section{A. B. P. FERNANDES: Yes, definitely. It'd be another version of it.}


NeIL BESNER: Of course, and you're a writer, you become a writer. A translator is a writer; there's no doubt about it. When you're writing a book, you come to see the whole shape of the story in your head. And you're working on it; you're bringing your own vision to it all the time. And I'm sure that, if a native speaker of Brazilian Portuguese, who's lived in Brazil, and understands the culture, he or she is writing from inside the culture. And so, for example, a Brazilian would tend to see Bishop more as a foreign than I would.

\section{A. B. P. FERNANDES: Yes, probably.}

NeIL Besner: A Brazilian would write a very different book. Now some parts of the American public might like the book more. I suspect that other parts would like it less. They would find it stranger, more "other".

\section{A. B. P. FERNANDES: Yes, “other”, that's the point.}

NEIL BESNER: But the other question is this, who are you translating for? And what should you be faithful to? The first time I wrote the first draft of this, I thought, "okay, eu vou ser literal. Literal. Vou fazer as minhas frases como se fossem em português.” Mas não dá, não dá mesmo.

\section{A. B. P. FERnANDES: Yes, because it's not English.}

NeIL BeSNER: Yes, you can't. It's not English. It's just a completely different thing. And so, I thought, "okay, this is it." My wife is a poet. She read it, and said, "This is really wooden. It is not English. What are you doing? Who are your readers?" So I wrote it again, and I tried to make it into English. And then, the problem is this... Actually, I should send you a paper I wrote about this. I gave a paper in last October in Canada about translation and appropriation. And the problem is this: on one hand, you're writing in English to an English audience, and the book has to stand its own. So, in this sense, you have to murder Portuguese. You have to erase, you have to say, okay, I have to give them the book that says what the Portuguese version says, but, as well, they don't speak Portuguese. And they have this book in front of them. It has to be self-sufficient, autonomous. It has to say what it says in English about the foreign culture.

\section{A. B. P. FERNANDES: You have to adapt it.}

NeIL BESNER: And, uhm, I don't think that you ever totally succeed on doing that. And there's an ethics in it, as well, and there's a morality in it. You sit there and say, "Well, who am I loyal to here? And how much to bend there? How much do I surrender?” If you give me your e-mail, I'll send you a paper I wrote. It's all about that. And I don't know the answer.

A. B. P. FERNANDES: That's what I'm in charge of now: to look for the things that were made explicit and omitted in the translation. 
NeIL Besner: Yes, good. You know what you should do? Maybe you should try translating a chapter, or translating a couple of pages, or just taking a section, and translate it. And then, don't look at my translation, then take a look at them, and see what the differences are.

A. B. P. FERnANDEs: Okay. And just one more question. It's just a matter of curiosity now... What about when Edileusa says, "Ó, minha Senhora da Boa Morte.", and you translate it as, "My Blessed Lady of the Good Death, my Sacred Heart of Jesus...", does it have the same effect in English?

NeIL BeSNER: Good question. We thought for a long time about it; this is a good example of whether we would translate it literally [which we did], whether not. There's no expression like that in English, but there's also no character like Edileusa in English, either. So, what do you do? Now, the literal answer for your question is no. It doesn't have the same effect.

\section{A. B. P. FERnANDES: Especially because Brazil is a very Catholic country.}

Neil Besner: Exactly. I'll give you another example. At the end of one chapter, Lota says to Bishop, "vá à merda.” In English, it would be "go to shit.” Não dá. So we thought, we thought, and we thought, and said, "oh, well, "fuck you", which is the equivalent kind of feeling and sensation. Now it means a totally different thing. But, in keeping with the relation between the two characters, in that case, we did shift the register in English. And, in this case, we didn't, because Edileusa seemed like a character, and we wanted to preserve Edileusa as a character. Because, if you read the whole book, she painnts, and she paints the garbage cans, and she marries a guy, and she has a poor relationship, and then, actually, she leaves. And we wanted to preserve her as an extraordinary character. So one of the ways to do that was to have her uttering these things. But you're right; they don't have the same presence in English. Now, let's suppose we have done the other way, and turned her into an American Southern woman. Then, would be saying, “oh, blessed Mammy”...

\section{A. B. P. FERNANDES: [laughs]}

NeIL Besner: Né? Mas não dá... Não dá because that is not the kind of person she is.

\section{A. B. P. FERNANDES: Yes, that's right.}

NeIL Besner: And the relationship between Edileusa and Lota, the boss... The patrão-empregado relationship is not equivalent to the Southern plantation on his relationship to the slave.

\section{A. B. P. FERnANDEs: Oh, yes, definitely.}

NEIL BESNER: They're different; they're related, but they're different.

\section{A. B. P. FERNANDEs: That's very exotic...}


NeIL BesneR: Here's another thing: how do you transmit to Americans that relationship between uma empregada e um dono. What I perceive is that, in Brazil, a relação entre dono e empregado tem alguns aspectos parentais. Conhece? "Meu filho", "minha filha”, em certos sentidos, é uma relação íntima.

\section{A. B. P. FERNANDES: Yeap.}

NeIL Besner: Nos Estados Unidos, não.

\section{A. B. P. FERNANDES: No, not at all.}

NeIl Besner: No, it's a very different kind of relationship. How do you transmit that? Because, when the Americans read about maids and domestics in Brazil, they think that they understand, but they don't understand. It's different. How do you transmit that? How do you convey the relationship between Lota and Edileusa to an American reader?

\section{A. B. P. FERNANDES: I got your point now.}

NeIL BeSNER: And Bishop was fascinated with Edileusa, absolutely fascinated by her. And she used to go round, and she used to learn her Portuguese from Edileusa. Porque Lota falava em inglês com ela, e Mary Morse falava em inglês com ela. Mas o português da Edileusa era, assim, o português do mato também. E ela falava essas encantações ao Santo Jesus e tudo isso, e, também, ela cantava canções tradicionais do mato. E a Bishop ficava lá, escutando e escrevendo. Então, o que é que nós vamos fazer? E eu pensei, "não, temos que preservar o que..." O título de um dos capítulos é "Era uma vez um Rei Chinês." Era a Edileusa que cantava isso na cozinha, e a Bishop ia escrevendo. A Carmen escrevendo o livro dela, fez um recorte disso. E fez o título de um capítulo com as palavras da Edileusa. O quê que eu vou fazer em inglês? Eu botei, “There was once a Chinese King” - that's the title of the chapter. But, then, if I do that, I've got to reproduce Edileusa's speech. And I've got to convey somehow, someway the relationship between Lota and Manuelzinho, Edileusa and Bishop, which is complicated.

\section{A. B. P. FERnANDES: Yes, that's a very hard task.}

NEIL BESNER: It's one of those cases, I think, that cultures are not totally translatable. They shouldn't be translatable. They should be strange. Language is not transparent. I think the mistake that then happens is when people say, "Well, I can't understand, I'll exoticise it. It's just sultry, erotic, or is...” Né? Aí vêm todos aqueles orientalised culture. But some things you can't translate, and, so, make them strange. However, back to your original point, I think if you translated it, it would be different. Because you have a different understanding of what is "normal" and what is "strange." And you have a different understanding of "empregados $e$ patrões", than I do. When I grew up in Brazil, I grew up as a foreigner, so my Portuguese is learned, and my perceptions are learned; they're "second perceptions." Nós fizemos uma entrevista com a Maria Lúcia, escrevi isso, e, depois em outubro de 2002, eu fui pra uma outra faculdade no Canadá e dei uma palestra sobre Tradução. E o título da palestra era "Cultural Appropriation"; how does 
translation get into "cultural appropriation"? 4 In other words, when you translate, are you stealing? Are you robbing? Are you surrendering? Which is the most powerful culture? What are you doing? What are the ethics of the acts? And I believe in translation. I think translation is a good thing. It has to happen all the time, and thank God for translation. Otherwise, there'd be lots of things we wouldn't live. At the same time, it's complicated. And you know, there's another thing, too. One of the dangers is to get paralysed. You sit there and say, "tem isso, isso $e$ isso $e$ isso... Com esses problemas todos, não posso fazer nada..." And I think that's the worst thing. Then there's nothing... And the other thing is I don't think that I could ever translate English into Portuguese. I can't do it. I don't understand Portuguese well enough.

\title{
A. B. P. Fernandes: But do you write well in Portuguese?
}

NeIL BESNER: Not particularly well. I don't think I do. I've given academic papers in Portuguese, and I write e-mails in Portuguese e falo português. Mas falar português e escrever são duas coisas completamente diferentes pra mim. I don't think that I write particularly well, no. I can make myself understood, sure, and, more or less, correctly, but no, I don't write particularly well in Portuguese.

\section{A. B. P. FERNANDES: Well, this is all very, very good.}

NEIL BESNER: É isSo só?

\section{A. B. P. FERNANDES: Thank you very much.}

NeIL BESNER: You're welcome.

\author{
Neil Besner \\ n.besner@uwinnipeg.ca \\ Dr., University of Winnipeg \\ Alinne Balduino P. Fernandes \\ alinnef@gmail.com \\ Dra., Universidade de São Paulo \\ Maria Lúcia Vasconcellos \\ maria.vasconcellos@ufsc.br \\ Dra., Universidade Federal de Santa Catarina
}

\footnotetext{
${ }^{4}$ Besner's paper has been published under the title "Translating North and South: Elizabeth Bishop, Biography, and Brazil.” In: Canadian Cultural Exchange/ Echanges culturels au Canada: Translation and Transculturation/ Traduction et transculturation, CHEADLE, Norman and PELLETIER, Lucien (eds.), Waterloo, Ontario: Wilfrid Laurier University Press (2007), 307-321.
} 


\section{Works cited}

AIXELÁ, Javier Franco. 1996. “Culture-Specific Items in Translation.” In: Translation, Power and

Subversion, AvarréZ, Román and VIDAL, M. Carmen-África (eds.), Clevedon: Multilingual Matters, 52-78.

BESNER, Neil. 1988. The Light of Imagination: Mavis Gallant's Fiction. Vancouver: University of

British Columbia Press.

. 1990. Introducing Alice Munro's "Lives of Girls and Women.” Toronto: ECW Press.

. 20007. "Translating North and South: Elizabeth Bishop, Biography, and Brazil.” In:

Canadian Cultural Exchange/ Echanges culturels au Canada: Translation and Transculturation/ Traduction et transculturation, CHEADLE, Norman and Pelletier, Lucien (eds.), Waterloo, Ontario: Wilfrid Laurier University Press, 307-321.

Fernandes, Alinne and Vasconcellos, Maria Lúcia. 2008. "Explicitação e Omissão de Categorias Culturais em Flores Raras e Banalíssimas e Rare and Commonplace Flowers: Um Estudo baseado em Corpus de Pequena Dimensão". TradTerm 14 (1): 73-101.

OliveIRA, Carmen. 1995. Flores Raras e Banalíssimas. Rio de Janeiro: Rocco. . 2002. Rare and Commonplace Flowers: The Story of Elizabeth Bishop and Lota Macedo de Soares. BESNER, Neil (trans.), New Jersey: Rutgers University Press. 